\title{
Faktor Penentu Kepuasan Kerja Karyawan Outsourcing di Perbankan
}

\author{
Ira Widyastuti
}

STIA Setih Setio Muara Bungo

ira.widyastuti.mm@gmail.com

\begin{abstract}
This study aimed to analyze the analysis of the determinants of job satisfaction employee outsourcing at BRI Limited Liability Company Branch Bangkoand influence on the performance. This research usesjob satisfaction variablesand performanceto analyzefactors determinant of job satisfaction employee outsourcingat BRI Limited Liability Company Branch Bangko. Besides that, to analyze influence on the performance.The population in this study is all employee outsourcing at BRI Limited Liability Company BranchBangkofrom all divisions of the company. Both of which have a contractual term of less than one year or more than one year. This population is totaling 63 employeesinclude the following frontliner (Custumer service dan teller), PAU, IT, TKK, Secretary, payment point, driver, servant, and security. In this research uses survey methods namely with giving questionnaire to all of population is totaling 63 employees consists of employee outsourcing in all parts of the company. Data collectedusing questionnaire methodnamely with giving questionslist or questionnaire directly to respondents. Technical analysis of the data in this research uses factor analysis by program SPSS.The resulted of research showed that factor analysis found as main factor which influence satisfaction employee outsourcing at BRI limited liability company is work environment. The resulted of second hypothesis testing found that job satification unsignificant to satisfaction employee outsourcing at BRI limited liability company.
\end{abstract}

Keywords: Job satisfaction; Employee outsourcing; Performance

\begin{abstract}
ABSTRAK
Penelitian ini bertujuan untuk menganalisis analisis faktor-faktor penentu kepuasan kerja karyawan outsourcing pada BRI Perseroan Terbatas Cabang Bangkoand terhadap kinerja. Penelitian ini menggunakan variabel kepuasan kerja dan kinerja untuk menganalisis faktorfaktor penentu kepuasan kerja karyawan di luar mengingat BRI Perseroan Terbatas Cabang Bangko. Selain itu, untuk menganalisis pengaruh pada kinerja. Populasi dalam penelitian ini adalah semua karyawan outsourcing di BRI Perseroan Terbatas Cabang dari semua divisi perusahaan. Keduanya memiliki jangka waktu kontrak kurang dari satu tahun atau lebih dari satu tahun. Populasi ini adalah total 63 karyawan termasuk garis depan berikut (Custumer service dan teller), PAU, IT, TKK, Sekretaris, titik pembayaran, pengemudi, pelayan, dan keamanan. Dalam penelitian ini menggunakan metode survei yaitu dengan memberikan kuesioner kepada seluruh populasi yang berjumlah 63 karyawan terdiri dari karyawan outsourcing di seluruh bagian perusahaan. Data dikumpulkan dengan menggunakan metode kuesioner secara langsung dengan memberikan daftar pertanyaan atau kuesioner langsung kepada responden. Analisis teknis data dalam penelitian ini menggunakan analisis faktor dengan program SPSS. Hasil penelitian menunjukkan bahwa analisis faktor yang ditemukan sebagai faktor utama yang mempengaruhi kepuasan karyawan outsourcing di BRI perseroan terbatas adalah lingkungan kerja. Hasil pengujian hipotesis kedua menemukan bahwa kepuasan kerja tidak signifikan terhadap kepuasan karyawan outsourcing di BRI perseroan terbatas.
\end{abstract}

Kata kunci: Kepuasan kerja; Outsourcing karyawan; Kinerja 


\section{PENDAHULUAN}

Mempekerjakan karyawan dalam ikatan kerja outsoucing nampaknya sedang menjadi trend atau model bagi pemilik atau pemimpin perusahaan baik itu perusahaan milik negara maupun perusahaan milik swasta. Banyak perusahaan outsourcing yakni perusahaan yang bergerak di bidang penyedia tenaga kerja aktif menawarkan keperusahaan-perusahaan pemberi kerja, sehingga perusahaan yang memerlukan tenaga tidak perlu susah-susah mencari, menyeleksi dan melatih tenaga kerja yang dibutuhkan (Gunarto, 2006).

Setiap perusahaan akan selalu berusaha untuk meningkatkan kinerja karyawan dengan harapan apa yang menjadi tujuan perusahaan akan tercapai. Berbagai cara akan ditempuh oleh perusahaan dalam meningkatkan kinerja karyawannya termasuk karyawan outsourcing. Agar kepuasan kerja karyawan selalu konsisten maka setidak tidaknya perusahaan selalu memperhatikan lingkungan dimana karyawan melaksanakan tugasnya yang berhubungan dengan Reward, pekerjaan, rekan kerja, promosi, supervisi, dan hal-hal lain yang dapat mempengaruhi kemampuan seseorang dalam menjalankan pekerjaannya.

Pada dasarnya bahwa seseorang dalam bekerja akan merasa nyaman dan tinggi kesetiannya pada organisasinya, apabila dalam pekerjaannya merasakan kepuasan sesuai dengan apa yang diinginkannya. Menurut kotler (2003) dalam irda (2007) karyawan adalah konsumen internal yang utama. Hal ini sejalan dengan apa yang di kemukakan oleh robbins (2002) yang menegaskan bahwa karyawanlah orang yang pertama harus di perhatikan bilamana organisasi akan meningkatkan kepuasan terhadap pelanggan yang dihadapi.Handoko (1992) menyatakan bahwa kepuasan kerja adalah keadaan emosional yang menyenangkan atau tidak menyenangkan dengan mana karyawan memandang pekerjaannya

Phenomena pro kontra terhadap keberadaan tenaga outsourced menimbulkan ketidaknyamanan bagi para tenaga outsorced di Indonesia termasuk di BRI cabang Bangko. Berdasarkan undang-undang No. 13 Tahun 2003 Pasal 59 ayat 4 yang berbunyi waktu tertentu dapat diadakan untuk paling lama 2 (dua) tahun dan hanya boleh diperpanjang 1 (satu) kali untuk jangka waktu paling lama 1 (satu) tahun. Terungkap berbagai keluhan, beberapa keluhan antara lain pencapaian dari tenaga outsourcing yang tidak secara langsung mempengaruhi kejelasan status mereka, ketidakpastian tenaga kerja sebagai tenaga outsourcing untuk diproses guna menampakkan perubahan status. Dari hasil penelitian awal terungkap bahwa dibanding dengan tenaga tetap, tenaga outsourcemerasa ada masalah dalam kepuasan kerja. 


\section{Outsourcing}

Outsourcing diartikan sebagai pelaksanaan perekrutan tenaga fungsional untuk menangani unit-unit kegiatan bisnis di luar kegiatan utama bisnis tersebut (Dominguez2006) satu bentuk yang lebih tampak perubahan organisasi. Studi baru-baru ini menunjukkan bahwa $85 \%$ perusahaan Amerika Utara dan Eropa sudah meng-outsource sedikitnya satu fungsi. Hal ini membangkitkan miyaran dollar dari kontrak-kontrak outsource (Elmuti et al.,1997). Outsourcing adalah mengkontrakkan kegiatan bisnis non-inti ke sumber luar. Kegiatan ini sudah umum diterapkan dalam sistem informasi dan teknologi (40\%), real estate (15\%), logistik (15\%), dan administrasi, sumber daya manusia, pelayanan konsumen, keuangan, pemasaran, penjualan dan transportasi (30\%) (Elmuti et al,1997).

Outsourcing dapat menimbulkan pergolakan yang besar. Pemogokan dapat dimulai oleh para pekerja yang diperlakukan kepada outsourcing, banyak pekerja yang merasa bahwa perusahaan yang memperkerjakan mereka tidak lagi membutuhkan mereka sehingga mereka mencari pekerjaan lain khususnya jika mereka memiliki keahlian-keahlian personal Gupta and Gupta (1992).

Laribee dan Michaels-Barr (1994) menyatakan bahwa outsourcing bisa berpengaruh kurang baik terhadap para pekerja dan banyak peralihan atau transisi yang berakibat kepada kinerja yang kurang optimal, memperkirakan bahwa ada tiga hal yang berkontribusi dalam respons pekerja terhadap outsourcing, yang pertama disebut "context" (Venkatesan 1992) mengemukakan prinsip-prinsip untuk memperkirakan keputusan outsourcing. Ia menyarankan bahwa perusahaan harus fokus pada setiap komponen yang secara jelas memiliki keunggulan, sementara komponen- komponen yang lain di-outsource oleh pihak luar dimana para pemasok memiliki keunggulan komparatif yang jelas. (McIvor 2000) mengemukakan empat langkah dalam memutuskan outsourcing yaitu tentukan aktivitas inti dari bisnis, evaluasi relevansi aktivitas-aktivitas rantai nilai, perhitungkan total biaya dari aktivitas inti bisnis dan analisis hubungan.

Dalam UU No.13/2003, yang menyangkut outsourcing adalah pasal 64, pasal 65 (terdiri dari 9 ayat), dan pasal 66 (terdiri dari 4 ayat). Pasal 64 adalah dasar dibolehkannya outsourcing . Dalam pasal 64 dinyatakan bahwa: Perusahaan dapat menyerahkan sebagian pelaksanaan pekerjaan kepada perusahaan lainnya melalui perjanjian pemborongan pekerjaan atau penyediaan jasa pekerja/buruh yang dibuat secara tertulis."

Kepuasan kerja merupakan suatu sikap umum terhadap pekerjaan seseorang, selisih antara banyaknya ganjaran yang diterima seorang pegawai dan banyaknya yang mereka yakini 
apa yang seharusnya mereka terima (Robbins, 2002; Darma et al, 2019). Kepuasan kerja dinikmati dalam pekerjaan, luar pekerjaan, dan kombinasi dalam dan luar pekerjaan (Hasibuan, 2001; Widastra dan Darma, 2015). Kepuasan kerja juga didefinisikan sebagai suatu sikap umum seseorang individu terhadap pekerjaannya. Pekerjaan menuntut interaksi dengan rekan kerja, atasan, peraturan dan kebijakan organisasi, standar kinerja, kondisi kerja dan sebagainya.Seorang dengan tingkat kepuasan kerja itu, sebaliknya seseorang tidak puas dengan pekerjaannya menunjukkan sikap negatif terhadap kerja itu (Robbins, 2002).

Pemahaman tentang kepuasan kerja dapat terwujud apabila analisis tentang kepuasan kerja dikaitkan dengan kinerja, tingkat kemangkiran, keinginan pindah, usia, jabatan dan besar kecilnya organisasi. (Siagian, 2002; Dewi dan Darma, 2017). Kepuasan kerja berhubungan dengan variabel-variabel seperti turnover, tingkat absensi, umur, tingkat pekerjaan dan ukuran organisasi.Hal ini sesuai dengan pendapat Davis dalam Mangkunegara (2005).

Kinerja karyawan merupakan suatu hasil yang dicapai oleh pekerja dalam pekerjaannya menurut kriteria tertentu yang berlaku untuk suatu pekerjaan tertentu. Robbins (2002) menyatakan bahwa kinerja karyawan adalah fungsi dari interaksi antara kemampuan dan motivasi. Simamora (2001) menyatakan bahwa maksud penetapan tujuan kinerja adalah menyusun sasaran yang berguna tidak hanya bagi evaluasi kinerja pada akhir periode tapi juga untuk mengelola proses kerja selama periode tersebut. As'ad (1995) menyatakan bahwa kinerja karyawan merupakankesuksesanseseorang di dalam melaksanakan suatu pekerjaan.Menurut Bernardin dan Russel (1993) ada 6 kriteria yang digunakan untuk mengukur sejauh mana kinerja karyawan secara individu, yaitu kualitas, kuantitas, ketepatan waktu, efektivitas, kemandirian, dan komitmen kerja.

Menurut A. Dale Timple dalam mangkunegara ( 2006) faktor kinerja terdiri dari faktor internal dan eksternal. Faktor internal (disposisional) yaitufaktor yang dihubungkan dengan sifat-sifat seseorang. Sedangkan Fakor eksternal yaitu faktor-faktor yang mempengaruhi kinerja seseorang yang berasal dari lingkungan seperti perilaku, sikap dan tindakan bawahan ataupun rekan kerja, fasilitas kerja dan iklim organisasi.

Kualitas kehidupan kerja merupakan masalah utama yang patut mendapat perhatian organisasi Lewis dkk (2001) Hal ini merujuk pada pemikiran bahwa kualitas kehidupan kerja dipandang mampu untuk meningkatkan peran serta dan sumbangan paraanggota atau karyawan terhadap organisasi. Penelitian juga menunjukkan adanya hubungan positif antara praktek kualitas kehidupan kerja dengan kinerja karyawan (Elmuti dan Kathawala, 1997; Widiari dan Darma, 2017) Kinerja dapat diukur melalui lima indikator yaitu Kualitas, Kuantitas, 
Pengetahuan dan ketrampilan, Ketepatan waktu, Komunikasi, Sedangkan menurut Dessler dalam rivai (2001) penilaian kinerja merupakan upaya membandingkan prestasi aktual karyawan dengan prestasikerja yang diharapkan darinya.Adapun faktor-faktor yang mempengaruhi pencapaian kinerja adalah Kemampuan, Efektivitas dan efisiensi, Otoritas dan tanggung jawab, Disiplin dan inisiatif.

Faktor- faktor penentu kepuasan kerja karyawan outsourced di PT.Bank Rakyat Indonesia (persero) tbk cabang bangko dan pengaruhnya terhadap kinerja.

\section{Kerangka Konseptual}

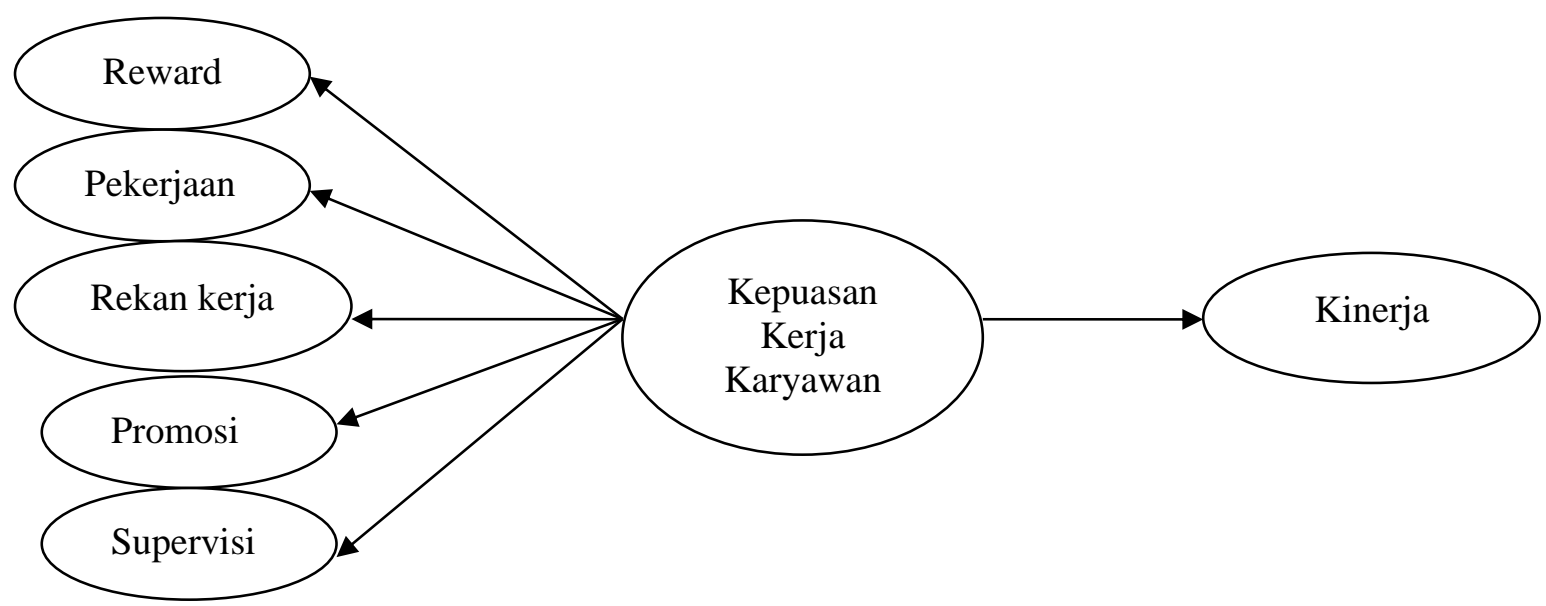

\section{Hipotesis}

Berdasarkan penjelasan diatas dan perumusan masalah maka penulis mengangkat hipotesis yang akan dibuktikan dalam penelitian ini adalah:

H 1 : Reward, pekerjaan, rekan kerja, promosi dan supervise merupakan predictor / penentu kepuasan kerja karyawan Outsoured PT. Bank Rakyat Indonesia (Persero) tbkCabang Bangko.

H 2 : Kepuasan kerja berpengaruh positif terhadap kinerja PT. BankRakyat Indonesia (Persero) tbk Cabang Bangko

\section{METODE PENELITIAN}

\section{Pendekatan dan Obyek Penelitian}

Dalam penelitian ini menggunakan metode penelitian deskriptif kuantitatif dengan analisis faktor. Penelitian ini akan dilaksanakan pada PT BRI (Persero) tbkCabang Bangko.PT BRI (Persero) tbk Cabang Bangko, yang berlamat di Jl Bangko Rendah No. 3 Penelitian ini 
menggunakan kuesioner untuk memperoleh informasi, yang disebarkan kepada seluruh karyawan PT BRI (Persero) tbk Cabang Bangko.PT BRI (Persero) tbkCabang Bangko salah satu cabang dari wilayah Palembang yang memiliki 9 Unit BRI dan 3 teras BRI yang berada di seluruh kecamatan dan kota di bangko.

\section{Populasi dan sampel}

Pada penelitian ini yang menjadi populasi dan sampel adalah seluruh karyawan outsorcedPT BRI (Persero) tbk Cabang Bangko yang berjumlah 63 orang karyawan.karena jumlah populasi di bawah 100 maka semua populasi dimasukkan jadi responden.Berikut ini adalah tabel jumlah karyawanPT BRI (Persero) tbkCabang Bangko.

\section{Jumlah Karyawan Outsourced Berdasarkan Bidang Pekerjaan}

\begin{tabular}{|l|c|}
\hline \multicolumn{1}{|c|}{ Bidang Pekerjaan } & Jumlah \\
\hline Frontliner(Custumer Service dan Teller) & 48 \\
\hline PAU & 1 \\
\hline Petugas IT & 1 \\
\hline Petugas TKK & 1 \\
\hline Petugas Sekretaris & 1 \\
\hline Payment Point & 1 \\
\hline Pengemudi & 3 \\
\hline Pramubakti Jumlah & 2 \\
\hline Satpam $\quad \mathbf{6 3}$ \\
\hline
\end{tabular}

Sumber : Data Periode februari 2012

\section{Instrumen Penelitian}

Bentuk instrumen pengumpulan data dalam penelitian ini adalah dengan mengunakan kusioner, dimana kusioner dari item-item dari kepuasan bersumber dari scott j.Vitell \& D.L Davis (1990) dari journal of business ethis dan kusioner dari kinerja bersumber dari Tsui, Anne S. Jone, L Peace \& Lyman Poter (1997).

Daftar skor Jawaban Setiap Pernyataan

\begin{tabular}{|l|c|}
\hline \multicolumn{1}{|c|}{ Alternatif Pertanyaan } & Bobot Pertanyaan \\
\hline Sangat setuju : SS & 5 \\
\hline Setuju : S : KS & 4 \\
\hline Kurang Setuju : TS & 3 \\
\hline Tidak setuju $\quad$ : STS & 1 \\
\hline Sangat tidak setuju & 1 \\
\hline
\end{tabular}




\section{Deskriptif Responden}

Tabel

Demografis Responden

\begin{tabular}{|c|c|c|}
\hline Keterangan & Jumlah & Percent \\
\hline \multicolumn{3}{|l|}{ Gender } \\
\hline Laki-Laki & 27 & 42.86 \\
\hline Perempuan & 36 & 57.14 \\
\hline \multicolumn{3}{|l|}{ Usia } \\
\hline$<24$ Tahun & 16 & 25.4 \\
\hline $24-35$ Tahun & 41 & 65.08 \\
\hline $36-45$ Tahun & 3 & 4.76 \\
\hline$>46$ Tahun & 3 & 4.76 \\
\hline \multicolumn{3}{|l|}{ Pendidikan } \\
\hline SMU / Sederajat & 10 & 15.87 \\
\hline Diploma & 8 & 12.70 \\
\hline S1 & 45 & 71.43 \\
\hline \multicolumn{3}{|l|}{ Lama Bekerja } \\
\hline$<1$ Tahun & 32 & 50.79 \\
\hline $1-2$ Tahun & 16 & 25.40 \\
\hline$>2$ Tahun & 15 & 23.81 \\
\hline
\end{tabular}

\section{HASIL PENELITIAN DAN PEMBAHASAN}

\section{Analisis Deskriptif}

\section{Distribusi Frekuensi Reward}

Tabel

Distribusi Frekuensi Reward

\begin{tabular}{|c|c|c|c|c|c|c|c|c|c|c|c|c|c|c|}
\hline \multirow{2}{*}{ No } & \multirow{2}{*}{ Reward } & \multicolumn{2}{|c|}{ SS } & \multicolumn{2}{|c|}{$\mathbf{S}$} & \multicolumn{2}{|c|}{$\mathbf{K S}$} & \multicolumn{2}{|c|}{ TS } & \multicolumn{2}{|c|}{ STS } & \multirow{2}{*}{ Mean } & \multirow{2}{*}{ TCR } & \multirow{2}{*}{ Ket } \\
\hline & & $\mathbf{F i}$ & $\%$ & $\mathbf{F i}$ & $\%$ & $\mathbf{F i}$ & $\%$ & $\mathbf{F i}$ & $\%$ & $\mathbf{F i}$ & $\%$ & & & \\
\hline 1 & $\begin{array}{l}\text { Instansi / organisasi } \\
\text { memberikan gaji yang lebih } \\
\text { baik dari instansi pesaing }\end{array}$ & 1 & 1.59 & 19 & 30.16 & 41 & 65.08 & 2 & 3.17 & 0 & 0.00 & 3.30 & 66.03 & Cukup \\
\hline 2 & $\begin{array}{l}\text { Gaji saya cukup, mengingat } \\
\text { tanggung jawab saya } \\
\text { terhadap pekerjaan }\end{array}$ & 0 & 0.00 & 10 & 15.87 & 38 & 60.32 & 13 & 20.63 & 2 & 3.17 & 2.89 & 57.78 & Kurang \\
\hline 3 & $\begin{array}{l}\text { Kenaikan gaji berdasarkan } \\
\text { pada prestasi kerja di } \\
\text { organisasi atau instansi ini }\end{array}$ & 1 & 1.59 & 8 & 12.70 & 33 & 52.38 & 18 & 28.57 & 3 & 4.76 & 2.78 & 55.56 & Kurang \\
\hline 4 & $\begin{array}{l}\text { Saya diberi gaji lebih } \\
\text { tendah untuk apa yang saya } \\
\text { kerjakan }(\mathrm{R})\end{array}$ & 0 & 0.00 & 2 & 3.17 & 48 & 76.19 & 13 & 20.63 & 0 & 0.00 & 2.83 & 56.51 & Kurang \\
\hline \multicolumn{12}{|c|}{ Total Skor Rata rata } & 2.95 & 58.97 & Kurang \\
\hline
\end{tabular}




\section{Distribusi Frekuensi Pekerjaan}

Tabel

Distribusi Frekuensi Pekerjaan

\begin{tabular}{|c|c|c|c|c|c|c|c|c|c|c|c|c|c|c|}
\hline \multirow{2}{*}{ No } & \multirow{2}{*}{ Pekerjaan } & \multicolumn{2}{|c|}{ SS } & \multicolumn{2}{|c|}{ S } & \multicolumn{2}{|c|}{ KS } & \multicolumn{2}{|c|}{ TS } & \multicolumn{2}{|c|}{ STS } & \multirow{2}{*}{ Mean } & \multirow{2}{*}{ TCR } & \multirow{2}{*}{ Ket } \\
\hline & & $\mathbf{F i}$ & $\%$ & $\mathbf{F i}$ & $\%$ & $\mathbf{F i}$ & $\%$ & $\mathbf{F i}$ & $\%$ & $\mathbf{F i}$ & $\%$ & & & \\
\hline 1 & $\begin{array}{l}\text { Pekerjaan saya saat ini } \\
\text { sangat menarik }\end{array}$ & 4 & 6.35 & 27 & 42.86 & 30 & 47.62 & 2 & 3.17 & 0 & 0.00 & 3.52 & 70.48 & Cukup \\
\hline 2 & $\begin{array}{l}\text { Saya merasa senang } \\
\text { dengan tingkat tanggung } \\
\text { jawabdalam pekerjaan } \\
\text { saya }\end{array}$ & 2 & 3.17 & 34 & 53.97 & 25 & 39.68 & 2 & 3.17 & 0 & 0.00 & 3.57 & 71.43 & Cukup \\
\hline 3 & $\begin{array}{l}\text { Suka lebih suka } \\
\text { melaksanakan pekerjaan } \\
\text { lain }\end{array}$ & 14 & 22.22 & 10 & 15.87 & 38 & 60.32 & 1 & 1.59 & 0 & 0.00 & 3.59 & 71.75 & Cukup \\
\hline 4 & $\begin{array}{l}\text { Pekerjaan menuntut saya } \\
\text { menggunakan } \\
\text { keterampilan tingkat } \\
\text { tinggi dan komplek }\end{array}$ & 3 & 4.76 & 33 & 52.38 & 22 & 34.92 & 4 & 6.35 & 1 & 1.42 & 3.52 & 70.48 & Cukup \\
\hline \multicolumn{12}{|c|}{ Total Skor Rata rata } & 3.55 & 71.03 & Cukup \\
\hline
\end{tabular}

\section{Distribusi Frekuensi Rekan Kerja}

Tabel

Distribusi Frekuensi Rekan Kerja

\begin{tabular}{|c|c|c|c|c|c|c|c|c|c|c|c|c|c|c|}
\hline \multirow{2}{*}{ No } & \multirow{2}{*}{ Rekan Kerja } & \multicolumn{2}{|c|}{ SS } & \multicolumn{2}{|c|}{$\mathbf{S}$} & \multicolumn{2}{|c|}{ KS } & \multicolumn{2}{|c|}{ TS } & \multicolumn{2}{|c|}{ STS } & \multirow{2}{*}{ Mean } & \multirow{2}{*}{ TCR } & \multirow{2}{*}{ Ket } \\
\hline & & $\mathbf{F i}$ & $\%$ & $\mathbf{F i}$ & $\%$ & $\mathbf{F i}$ & $\%$ & $\mathbf{F i}$ & $\%$ & $\mathbf{F i}$ & $\%$ & & & \\
\hline 1 & $\begin{array}{l}\text { Saya menikmati bekerja } \\
\text { dengan teman teman } \\
\text { dikantor }\end{array}$ & 5 & 7.94 & 31 & 49.21 & 24 & 38.10 & 2 & 3.17 & 1 & 1.39 & 3.59 & 71.75 & Cukup \\
\hline 2 & $\begin{array}{l}\text { Saya bekerja dengan orang } \\
\text { yang bertanggung jawab }\end{array}$ & 4 & 6.35 & 30 & 47.62 & 26 & 41.27 & 3 & 4.76 & 0 & 0.00 & 3.56 & 71.11 & Cukup \\
\hline 3 & $\begin{array}{l}\text { Rekan kerja saya } \\
\text { memberikan dukungan } \\
\text { yang cukup }\end{array}$ & 5 & 7.94 & 34 & 53.97 & 22 & 34.92 & 2 & 3.17 & 0 & 0.00 & 2.33 & 46.67 & Kurang \\
\hline 4 & $\begin{array}{l}\text { Ketika saya meminta } \\
\text { rekan kerja melakukan } \\
\text { pekerjaan tertentu, } \\
\text { pekerjaan itu selesai }\end{array}$ & 1 & 1.59 & 19 & 30.16 & 35 & 55.56 & 8 & 12.70 & 0 & 0.00 & 3.21 & 64.13 & Cukup \\
\hline \multicolumn{12}{|c|}{ Total Skor Rata rata } & 3.17 & 63.41 & Cukup \\
\hline
\end{tabular}

\section{Distribusi Frekuensi Promosi}

Tabel

Distribusi Frekuensi Promosi

\begin{tabular}{|c|c|c|c|c|c|c|c|c|c|c|c|c|c|c|}
\hline \multirow{2}{*}{ No } & \multirow{2}{*}{ Promosi } & \multicolumn{2}{|c|}{ SS } & \multicolumn{2}{|c|}{$\mathbf{S}$} & \multicolumn{2}{|c|}{$\mathbf{K S}$} & \multicolumn{2}{|c|}{ TS } & \multicolumn{2}{|c|}{ STS } & \multirow{2}{*}{ Mean } & \multirow{2}{*}{ TCR } & \multirow{2}{*}{ Ket } \\
\hline & & $\mathbf{F i}$ & $\%$ & $\mathbf{F i}$ & $\%$ & $\mathbf{F i}$ & $\%$ & $\mathbf{F i}$ & $\%$ & $\mathbf{F i}$ & $\%$ & & & \\
\hline 1 & $\begin{array}{l}\text { Dalam instansi atau } \\
\text { organisasi ini adanya } \\
\text { kesempatan yang sama bagi } \\
\text { semua karyawan untuk maju }\end{array}$ & 9 & 14.29 & 25 & 39.68 & 26 & 41.27 & 2 & 3.17 & 1 & 1.38 & 3.62 & 72.38 & Cukup \\
\hline 2 & $\begin{array}{l}\text { Ketika saya melaksanakan } \\
\text { pekerjaan dengan baik saya } \\
\text { akan di promosikan }\end{array}$ & 8 & 12.70 & 13 & 20.63 & 34 & 53.97 & 7 & 11.11 & 1 & 1.51 & 3.32 & 66.35 & Cukup \\
\hline 3 & $\begin{array}{l}\text { Saya puas dengan tingkat } \\
\text { kemajuan saya }\end{array}$ & 4 & 6.35 & 28 & 44.44 & 27 & 42.86 & 4 & 6.35 & 0 & 0.00 & 3.51 & 70.16 & Cukup \\
\hline 4 & $\begin{array}{l}\text { Saya tidak suka dengan } \\
\text { dasar pertimbangan yang } \\
\text { digunakan untuk promosi } \\
\text { dalam organisasi (R) }\end{array}$ & 0 & 0.00 & 8 & 12.70 & 42 & 66.67 & 12 & 19.05 & 1 & 1.72 & 3.10 & 61.90 & Cukup \\
\hline \multicolumn{12}{|c|}{ Total Skor Rata rata } & 3.38 & 67.70 & Cukup \\
\hline
\end{tabular}




\section{Distribusi Frekuensi Supervisi}

Tabel

Distribusi Frekuensi Supervisi

\begin{tabular}{|c|c|c|c|c|c|c|c|c|c|c|c|c|c|c|}
\hline \multirow{2}{*}{ No } & \multirow{2}{*}{ Supervisi } & \multicolumn{2}{|c|}{ SS } & \multicolumn{2}{|c|}{$\mathbf{S}$} & \multicolumn{2}{|c|}{ KS } & \multicolumn{2}{|c|}{ TS } & \multicolumn{2}{|c|}{ STS } & \multirow{2}{*}{ Mean } & \multirow{2}{*}{ TCR } & \multirow{2}{*}{ Ket } \\
\hline & & $\mathbf{F i}$ & $\%$ & $\mathbf{F i}$ & $\%$ & $\mathbf{F i}$ & $\%$ & $\mathbf{F i}$ & $\%$ & $\mathrm{Fi}$ & $\%$ & & & \\
\hline 1 & $\begin{array}{l}\text { Atasan memberikan } \\
\text { pengakuan dan penghargaan } \\
\text { pada keryawan yang telah } \\
\text { melakukan pekerjaan dengan } \\
\text { baik }\end{array}$ & 2 & 3.17 & 16 & 25.40 & 40 & 63.49 & 5 & 7.94 & 0 & 0.00 & 3.24 & 64.76 & Cukup \\
\hline 2 & $\begin{array}{l}\text { Para atasan tidak mau } \\
\text { mendengarkan saya }(\mathrm{R})\end{array}$ & 1 & 1.59 & 1 & 1.59 & 43 & 68.25 & 16 & 25.40 & 2 & 3.66 & 3.27 & 65.40 & Cukup \\
\hline 3 & $\begin{array}{l}\text { Manajemen tidak } \\
\text { memberlakukan saya dengan } \\
\text { jujur dan adil }(\mathrm{R})\end{array}$ & 1 & 1.59 & 0 & 0.00 & 47 & 74.60 & 13 & 20.63 & 2 & 3.62 & 3.24 & 64.76 & Cukup \\
\hline 4 & $\begin{array}{l}\text { Atasan mendorong saya } \\
\text { berusaha mencoba cara baru } \\
\text { dalam bekerja }\end{array}$ & 1 & 1.59 & 27 & 42.86 & 32 & 50.79 & 3 & 4.76 & 0 & 0.00 & 3.41 & 68.25 & Cukup \\
\hline & & & tal S & $\mathbf{r R}$ & rata & & & & & & & 3.29 & 65.79 & Cukup \\
\hline
\end{tabular}

\section{Distribusi Frekuensi Kinerja Karyawan}

Tabel

Distribusi Frekuensi Kinerja

\begin{tabular}{|c|c|c|c|c|c|c|c|c|c|c|c|c|c|c|}
\hline \multirow{2}{*}{ No } & \multirow{2}{*}{ Kepuasan } & \multicolumn{2}{|c|}{ SS } & \multicolumn{2}{|c|}{$\mathbf{S}$} & \multicolumn{2}{|c|}{ KS } & \multicolumn{2}{|c|}{ TS } & \multicolumn{2}{|c|}{ STS } & \multirow{2}{*}{ Mean } & \multirow{2}{*}{ TCR } & \multirow{2}{*}{ Ket } \\
\hline & & $\mathbf{F i}$ & $\%$ & $\mathbf{F i}$ & $\%$ & $\mathbf{F i}$ & $\%$ & $\mathbf{F i}$ & $\%$ & $\mathbf{F i}$ & $\%$ & & & \\
\hline 1 & $\begin{array}{l}\text { Kuantitas kerja melebihi } \\
\text { rata- rata karyawan lain }\end{array}$ & 2 & 3.17 & 16 & 25.40 & 43 & 68.25 & 2 & 3.17 & 0 & 0.00 & 3.29 & 65.71 & Cukup \\
\hline 2 & $\begin{array}{l}\text { Kualitas kerja saya } \\
\text { melebihi rata-rata karyawan } \\
\text { lain }\end{array}$ & 1 & 1.59 & 10 & 15.87 & 49 & 77.78 & 3 & 4.76 & 0 & 0.00 & 3.14 & 62.86 & Cukup \\
\hline 3 & $\begin{array}{l}\text { Efisiensi kerja melebihi rata } \\
\text { rata karyawan lain }\end{array}$ & 1 & 1.59 & 9 & 14.29 & 49 & 77.78 & 4 & 6.35 & 0 & 0.00 & 3.11 & 62.22 & Cukup \\
\hline 4 & $\begin{array}{l}\text { Standar kualitas saya } \\
\text { melebihi rata-rata karyawan } \\
\text { lain }\end{array}$ & 1 & 1.59 & 12 & 19.05 & 47 & 74.60 & 3 & 4.76 & 0 & 0.00 & 3.17 & 63.49 & Cukup \\
\hline 5 & $\begin{array}{l}\text { Saya memegang standar } \\
\text { professional yang lebih } \\
\text { tinggi }\end{array}$ & 2 & 3.17 & 10 & 15.87 & 48 & 76.19 & 3 & 4.76 & 0 & 0.00 & 3.17 & 63.49 & Cukup \\
\hline 6 & $\begin{array}{l}\text { Saya berusaha lebih keras } \\
\text { dari pada seharusnya }\end{array}$ & 4 & 6.35 & 20 & 31.75 & 33 & 52.38 & 6 & 9.52 & 0 & 0.00 & 3.35 & 66.98 & Cukup \\
\hline 7 & $\begin{array}{l}\text { Kemampuan saya } \\
\text { melaksanakan pekerjaan } \\
\text { inti bagus }\end{array}$ & 2 & 3.17 & 25 & 39.68 & 33 & 52.38 & 3 & 4.76 & 0 & 0.00 & 3.41 & 68.25 & Cukup \\
\hline 8 & $\begin{array}{l}\text { Kemampuan saya } \\
\text { menggunakan akal sehat } \\
\text { dalam melaksanakan } \\
\text { pekerjaan bagus }\end{array}$ & 3 & 4.76 & 28 & 44.44 & 29 & 46.03 & 3 & 4.76 & 0 & 0.00 & 3.49 & 69.84 & Cukup \\
\hline 9 & $\begin{array}{l}\text { Pengetahuan saya dalam } \\
\text { melaksanakan pekerjaan } \\
\text { bagus }\end{array}$ & 3 & 4.76 & 27 & 42.86 & 29 & 46.03 & 4 & 6.35 & 0 & 0.00 & 3.46 & 69.21 & Cukup \\
\hline 10 & $\begin{array}{l}\text { Pengetahuan saya berkaitan } \\
\text { dengan pekerjaan } \\
\text { utamanyaadalah baik }\end{array}$ & 2 & 3.17 & 28 & 44.44 & 30 & 47.62 & 3 & 4.76 & 0 & 0.00 & 3.46 & 69.21 & Cukup \\
\hline 11 & $\begin{array}{l}\text { Kreativitas saya dalam } \\
\text { melaksanakan pekerjaan } \\
\text { utamanya adalah baik }\end{array}$ & 2 & 3.17 & 27 & 42.86 & 30 & 47.62 & 4 & 6.35 & 0 & 0.00 & 3.43 & 68.57 & Cukup \\
\hline \multicolumn{12}{|c|}{ Rerata } & 3.32 & 66.35 & Cukup \\
\hline
\end{tabular}




\section{Pengujian Instrumen Data}

\section{Pengujian Validitas Data}

Pengujian validitas dibuat berdasarkan pendapat Ghozali (2011) dalam penelitian ini untuk tahapan pengujian validitas dilakukan dengan menggunakan model correlation product momentdibuat berdasarkan pendapat Hair et al (2008) masing masin item pertanyaan dinyatakan valid bila memiliki koefisien korelasi diatas atau sama dengan 0,30.

Tabel

Hasil Pengujian Validitas Kinerja Karyawan

\begin{tabular}{|l|c|c|c|}
\hline \multicolumn{1}{|c|}{ Item } & $\begin{array}{c}\text { Coefficient } \\
\text { correlation }\end{array}$ & $\begin{array}{c}\text { Nilai } \\
\text { Batas }\end{array}$ & Kesimpulan \\
\hline Kinerja $a_{1}$ & 0,580 & 0,30 & Valid \\
\hline Kinerja $_{1}$ & 0,569 & 0,30 & Valid \\
\hline Kinerja $_{1}$ & 0,528 & 0,30 & Valid \\
\hline Kinerja $_{1}$ & 0,557 & 0,30 & Valid \\
\hline Kinerja $_{1}$ & 0,668 & 0,30 & Valid \\
\hline Kinerja $_{1}$ & 0,595 & 0,30 & Valid \\
\hline Kinerja $_{1}$ & 0,772 & 0,30 & Valid \\
\hline Kinerja $_{1}$ & 0,834 & 0,30 & Valid \\
\hline Kinerja $_{1}$ & 0,813 & 0,30 & Valid \\
\hline Kinerja & 0,736 & 0,30 & Valid \\
\hline Kinerja $_{1}$ & 0,810 & 0,30 & Valid \\
\hline
\end{tabular}

\section{Pengujian Reliabilitas}

Pengujian reliabilitas dibuat berdasarkan pendapatGhozali (2011). Pengujian reliabilitas dilakukan dengan mencari nilai Cronbach,s Alpha.

Tabel

Hasil Pengujian Reliabilitas Kinerja Karyawan

\begin{tabular}{|c|c|c|c|}
\hline Variabel & $\begin{array}{c}\text { Cronbach's } \\
\text { Alpha }\end{array}$ & $\begin{array}{c}\text { Nilai } \\
\text { Batas }\end{array}$ & Kesimpulan \\
\hline Kinerja Karyawan & 0,918 & 0,60 & Reliable \\
\hline
\end{tabular}

\section{Pengujian Normalitas Data}

Di dalam menguji normalitas digunakan bantuan uji One Sample Kolmogorov Smirnov Test. Variabel penelitian dinyatakan normal apabila menghasilkan nilai asymp sig (2-Tailed)> alpha 0,05 yangdibuat berdasarkan pendapat santoso (2001)

Tabel

Hasil Pengujian Normalitas Variabel Penelitian

\begin{tabular}{|l|c|c|c|}
\hline \multicolumn{1}{|c|}{ Variabel } & $\begin{array}{c}\text { Asymp Sig } \\
\text { (2-Tailed) }\end{array}$ & Alpha & Kesimpulan \\
\hline Kinerja Karyawan & 0,104 & 0,05 & Normal \\
\hline Kepuasan & 0,732 & 0,05 & Normal \\
\hline
\end{tabular}




\section{Pengujian Hipotesis}

\section{Metode Analisis Faktor}

Metode analisis factor (factor analisys) merupakan sebuah analisis yang bertujuan mengelompokan sejumlah dimensi dengan kontribusi tertentu yang merupakan faktor yang mempengaruhi sebuah kejadian atau sebuah permasalahan tertentu.

\section{Analisis KMO (Kaiser Mayer-Oiken)}

Pengujian KMO yang berguna untuk menentukan kelayakan atau ketepatan dari setiap item yang akan diuji (Hair 2008). Berdasarkan hasil pengujian ditemukan hasil pengujian sebagai berikut:

Tabel

Analisis KMO (Kaiser Mayer Oiken)

$\mathrm{KMO}$ and Bartlett's Test

\begin{tabular}{|c|c|c|}
\hline \multicolumn{2}{|c|}{$\begin{array}{l}\text { Kaiser-Mey er-Olkin Measure of Sampling } \\
\text { Adequacy. }\end{array}$} & .792 \\
\hline $\begin{array}{l}\text { Bartlett's Test of } \\
\text { Sphericity }\end{array}$ & $\begin{array}{l}\text { Approx. Chi-Square } \\
\text { df } \\
\text { Sig. }\end{array}$ & $\begin{array}{r}508.724 \\
120 \\
.000\end{array}$ \\
\hline
\end{tabular}

\section{Anti Image Corelation}

Anti image correlationdari penelitian ini dibuat berdasarkan pendapat Hair et al (2008).Item pertanyaan yang di ikutsertakan adalah sub faktor yang memiliki nilai koefisien korelasi $\geq 0,40$.

\section{Communities}

Tabel

Cummunalities

\begin{tabular}{|c|c|c|}
\hline \multicolumn{3}{|c|}{ Communalities } \\
\hline & Initial & Extraction \\
\hline reward 3 & 1.000 & .760 \\
\hline reward_4 & 1.000 & .732 \\
\hline pekerjaan_1 & 1.000 & .663 \\
\hline pekerjaan_2 & 1.000 & .703 \\
\hline pekerjaan_4 & 1.000 & .822 \\
\hline rekan_kerja_1 & 1.000 & .779 \\
\hline rekan_kerja_2 & 1.000 & .777 \\
\hline rekan_kerja_3 & 1.000 & .591 \\
\hline rekan_kerja_4 & 1.000 & .747 \\
\hline promosi_1 & 1.000 & .752 \\
\hline promosi_2 & 1.000 & .806 \\
\hline promosi_3 & 1.000 & .640 \\
\hline supervisi_1 & 1.000 & .661 \\
\hline supervisi_2 & 1.000 & .852 \\
\hline supervisi_3 & 1.000 & .865 \\
\hline supervisi_4 & 1.000 & .754 \\
\hline
\end{tabular}




\section{Menerangkan Nilai Variance (Total Variance Explained)}

Tahapan analisis faktor keempat adalah Total variance explained, TotalVariance Explained merupakan sebuah analisis yang digunakan untuk melihat jumlah berapa faktor yang optimal dalam menjelaskan variance dari 16 item pertanyaan yang tersisa.

\section{Tabel}

Total Variance Explained

\begin{tabular}{|c|c|c|c|c|c|c|c|c|c|}
\hline \multirow{2}{*}{ Komponen } & \multicolumn{4}{|c|}{ Initial Eigenvalue } & \multicolumn{3}{c|}{$\begin{array}{c}\text { Extraction Sums od Square } \\
\text { Loading }\end{array}$} & \multicolumn{3}{c|}{ Rotation Sum of Square Loading } \\
\cline { 2 - 10 } & Total & $\begin{array}{c}\text { \% of } \\
\text { Variance }\end{array}$ & Comulative & Total & $\begin{array}{c}\text { \% of } \\
\text { Variance }\end{array}$ & Comulative & Total & $\begin{array}{c}\text { \% of } \\
\text { Variance }\end{array}$ & Comulative \\
\hline 1 & 5.822 & 36.388 & 36.388 & 5.822 & 36.388 & 36.388 & 3.307 & 20.667 & 20.667 \\
\hline 2 & 2.111 & 13.195 & 49.583 & 2.111 & 13.195 & 49.583 & 2.910 & 18.185 & 38.851 \\
\hline 3 & 1.481 & 9.259 & 58.842 & 1.481 & 9.259 & 58.842 & 2.678 & 16.738 & 55.589 \\
\hline 4 & 1.431 & 8.946 & 67.787 & 1.431 & 8.946 & 67.787 & 1.758 & 10.990 & 66.579 \\
\hline 5 & 1.057 & 6.605 & 74.392 & 1.057 & 6.605 & 74.392 & 1.250 & 7.813 & 74.392 \\
\hline
\end{tabular}

Analisis Rotasi Matrik

\section{Tabel}

Faktor-Faktor yang Mempengaruhi Kepuasan Kerja Di Lingkungan BRI Cabang Bangko 2012

\begin{tabular}{|c|c|c|c|c|}
\hline Faktor & Item & $\begin{array}{c}\% \text { of } \\
\text { Variance }\end{array}$ & $\begin{array}{l}\text { Nama } \\
\text { Faktor }\end{array}$ & $\begin{array}{c}\text { Nilai } \\
\text { Loading }\end{array}$ \\
\hline Faktor 1 & $\begin{array}{l}\text { Senang dengan pekerjaan dan tanggung jawab } \\
\text { Saya bekerja dengan orang yang bertanggung jawab } \\
\text { Meminta rekan kerja melakukan sesuatu } \\
\text { Saya puas dengan tingkat kemajuan } \\
\text { Atasan memberikan dorongan }\end{array}$ & 20,667 & $\begin{array}{c}\text { Lingkungan } \\
\text { Kerja }\end{array}$ & $\begin{array}{l}0,732 \\
0,844 \\
0,704 \\
0,534 \\
0,599\end{array}$ \\
\hline Faktor 2 & $\begin{array}{l}\text { Kenaikan gaji sesuai prestasi kerja } \\
\text { Pekerjaan saya saat ini sangat menarik } \\
\text { Kesempatan untuk maju bagi semua karyawan } \\
\text { Atas memberikan pengakuan dan penghargaan }\end{array}$ & 18,195 & $\begin{array}{c}\text { Aktualisasi } \\
\text { Diri }\end{array}$ & $\begin{array}{l}0,769 \\
0,692 \\
0,527 \\
0,751\end{array}$ \\
\hline Faktor 3 & $\begin{array}{l}\text { Dukungan dari rekan kerja } \\
\text { Atasan yang mau mendengar persepsi karyawan } \\
\text { Perlakuan adil dari atasan }\end{array}$ & 16,738 & Mentoring & $\begin{array}{l}0,634 \\
0,884 \\
0,894\end{array}$ \\
\hline Faktor 4 & Dorongan dari atasan tentang cara baru dalam bekerja & 10,990 & $\begin{array}{l}\text { Motivasi } \\
\text { eksternal }\end{array}$ & 0,610 \\
\hline Faktor 5 & Pekerjaan yang menuntut keterampilan tingkat tinggi & 7,813 & Kompetensi & 0,847 \\
\hline & Total Kontribusi & \multicolumn{3}{|c|}{74.392} \\
\hline
\end{tabular}

\section{Pengujian Hipotesis II}

\section{Pengujian R-Square $\left(\mathbf{R}^{\mathbf{2}}\right)$}

Pengujian R-square atau koefisien determinasi dibuat berdasarkan pendapat Hair et al (2008).

Tabel

Hasil Pengujian Koefisien Determinasi

\begin{tabular}{|l|l|r|r|r|}
\hline Model & $\mathrm{R}$ & R Square & $\begin{array}{c}\text { Adjusted R } \\
\text { Square }\end{array}$ & $\begin{array}{c}\text { Std. Error of } \\
\text { the Estimate }\end{array}$ \\
\hline 1 & $.142(\mathrm{a})$ & .020 & .005 & .14233 \\
\hline
\end{tabular}

a Predictors: (Constant), Kepuasan 


\section{Pengujian t-Statistik}

Pengujian uji t-statistik dibuat berdasarkan pendapat Hair et al (2008).

Tabel

Hasil Pengujian Hipotesis II

Coefficients

\begin{tabular}{|c|c|c|c|c|c|c|}
\hline \multirow[b]{2}{*}{ Model } & & \multicolumn{2}{|c|}{$\begin{array}{c}\text { Unstandardized } \\
\text { Coefficients }\end{array}$} & \multirow{2}{*}{$\begin{array}{c}\begin{array}{c}\text { Standardized } \\
\text { Coefficients }\end{array} \\
\text { Beta }\end{array}$} & \multirow[b]{2}{*}{$t$} & \multirow[b]{2}{*}{ Sig. } \\
\hline & & $B$ & Std. Error & & & \\
\hline & (Constant) & 3.357 & .206 & & 16.314 & .000 \\
\hline & Kepuasan & .004 & .003 & .142 & 1.123 & .266 \\
\hline
\end{tabular}

a. Dependent Variable: Kinerja Kary awan

Pada tabel pengaruh yang terbentuk anatara variabel independen dengan variabel dependen seperti terlihat dibawah ini:

$$
\mathrm{Y}=3,357+0,004 \mathrm{x}
$$

\section{Pembahasan}

\section{Faktor Dominan yang Mempengaruhi Kepuasan Kerja}

Berdasarkan kepada tahapan pengujian factor analysis diperoleh lima faktor utama yang mendorong terbentuknya kepuasan kerja karyawan outsourcing di lingkungan PT Bank Rakyat Indonesia (Persero) Tbk yaitu. Dari lima faktor yang terbentuk factor 1 adalah yang paling dominan karena memiliki kontribusi yang paling kuat diantara faktor lainnya. Temuan ini memperlihatkan bahwa karyawan outsourcing akan merasa nyaman dan puas bekerja ketika perusahaan mampu mengelola dan menciptakan lingkungan kerja yang kondusif dan saling mendukung. Dalam hal ini manajemen perusahaan harus dapat melakukan penempatan posisi karyawan sesuai dengan kompetensi yang mereka miliki, sehingga mereka menyukai dan dapat bertanggung jawab dengan bidang pekerjaan yang telah dilakukan. Perusahaan diharapkan juga dapat menciptakan lingkungan kerja yang harmonis, seperti terjalinnya kerja sama team yang baik dalam bekerja, baik dengan sesama rekan kerja maupun dengan atasan.

\section{Pengaruh Kepuasan Kerja Terhadap Kinerja Karyawan}

Sesuai dengan hasil pengujian hipotesis yang telah dilakukan ditemukan bahwa kepuasan kerja tidak berpengaruh signifikan terhadap kinerja karyawan di lingkungan PT Bank Rakyat Indonesia (Persero) Tbk Cabang Bangko. Hasil yang diperoleh tidak sejalan dengan hipotesis yang diajukan. Temuan yang diperoleh menunjukan bahwa kinerja karyawan outsourcing di lingkungan PT Bank Rakyat Indonesia (Persero) Tbk Cabang Bangko tidak 
dipengaruhi oleh kepuasan kerja, pada umumnya karyawan outsourcing berusaha membuktikan bahwa mereka juga memiliki tingkat kompetensi yang tinggi, walaupun status mereka hanya sebagai pegawai kontrak yang tidak mendapatkan fasilitas sebaik pegawai tetap tidak menghilangkan motivasi mereka didalam bekerja, mereka menyadari bahwa statusnya mereka hanya sebagai outsourcing penuh dengan tekanan dan jauh dari rasa puas dianggap sebagai situasi dan kondisi yang biasa, komitmen yang kuat didalam diri masing masing karyawan membuat mereka tetap menunjukan kompetensi diri lewat peningkatan prestasi yang ditandai dengan realiasi pencapaian target degan kuantitas dan kualitas yang terus meningkat.

\section{PENUTUP}

Berdasarkan uraian analisis dan pembahasan hasil pengujian hipotesis, maka dapat diajukan beberapa kesimpulan penting yang merupakan inti jawaban dari masalah yang dibahas yaitu: Hasil pengujian faktor analysis ditemukan bahwa faktor utama yang mempengaruhi kepuasan karyawan outsourcing di lingkungan PT Bank Rakyat Indonesia (Persero) Tbk adalah lingkungan kerja faktor utama karena memiliki kontribusi lebih besar dari empat faktor lainya. Total kontribusi yang dibentuk oleh lima faktor utama adalah sebesar 74,392\%.Hasil pengujian hipotesis kedua ditemukan bahwa kepuasan kerja tidak berpengaruh signifikan terhadap kepuasan karyawan outsourcing di lingkungan PT Bank Rakyat Indonesia (Persero) Tbk. 


\section{DAFTAR PUSTAKA}

As'ad, M. (1995). Kepemimpinan Efektif dalam Perusahaan, Suatu Pendekatan Psikologik, Edisi Kedua. Yogyakarta: Liberty.

Bernadin, H.J., \& Russell, J.E.A. (1993). Human resource management, International edition. Singapura: McGraw Hill,Inc.

Dominguez, L.R. (2006). The Manager's step-by-step guide to outsourcing. New York: McGraw-Hill.

Darma, G.S., Wicaksono, K., Sanica, I.G., and Abiyasa, A.P. (2019). Faktor Kompensasi dan Strategi Gojek Dalam Meningkatkan Kepuasan Kerja Para Driver, Jurnal Ilmiah Manajemen Bisnis dan Inovasi Universitas Sam Ratulangi, 6 (3): 232-244.

Dewi, A.A.I.S., and Darma, G.S. (2017). Proses Rekrutmen, Seleksi, Pelatihan, Penempatan dan Kinerja Karyawan, Jurnal Manajemen \& Bisnis, 14 (1): 1-18.

Elmuti, D., Kathawala, Y. (1997). An Investigation into Effects of ISO 9000 on Participants' Attitudes and Job Performance, Production and Inventory Management Journal, Second Quarter.

Ghozali, I. (2011). Analisis Multivariate dengan Menggunakan SPSS 20. BPFE: Yogyakarta.

Gunarto, S. (2006). Perlindungan Hukum Bagi Para Pekerja Kontrak Outsourcing, Yogyakarta: Universitas Atma Jaya.

Gupta, U.T., dan Gupta, A. (1992). Outsourcing the IS Function: Is it Necessary for Your Organization?, Information Management Systems, Summer: 44-50.

Handoko, H. (1992). Manajemen Personalia dan Sumber Daya Manusia. Yogyakarta: BPFE. Hair, J.F., Black., W.C., dan Barry, J.B., dan Anderson, R.E. (2008). Multivariate Data Analisysis. Prentice Hall.

Hasibuan, M. (2001). Manajemen Sumber Daya Manusia. Jakarta: PT. Bumi Aksara.

Irda. (2007). Analisis Penentu Kepuasan Kerja Karyawan Dalam Bidang Usaha Jasa: Suatu Tinjauan Teori, Jurnal Manajemen Universitas Bung Hatta, 2 (1): 41-45.

Laribee, J.F., dan Michaels-Barr, L. (1994). Dealing with Personnel Concerns in Outsourcing, Journal of Systems Management, January: 6-10.

Lewis, D., Brazil, K., Krueger, P., Lohfeld, L., and Tjam, E. (2001). Extrinsic and Intrinsic Determinants of Quality of Work Life, International Journal of health Care Quality Assurance Incorporating Leadership in Health Service, 14: 9-15.

Mangkunegara, A.P. (2005). Evaluasi Kinerja Manajemen Sumber Daya Manusia. Bandung: Remaja Rosda Karya.

Mayuza, A. (2009). Pengaruh Kepuasan Kerja Dalam Memediasi Hubungan Antara Motivasi 
Dengan Intensi Turn Over Pegawai Pada Satuan Kerja Perangkat Daerah X Kota Y. Tesis. Program Pascasarjana Universitas Andalas, Padang.

McIvor, R. (2000). A Practical Framework for Understanding The Outsourcing Process, Supply Chain Management: An International Journal, 5 (1): 22-36.

Rivai, H.A., dan Pramusinto. (2001). Pengaruh motivasi, komitmen organisasional dan kompetensi terhadap kinerja individual.Artikel Ekonomi

Robbin, P.S. (2002). Perilaku Organisasi, Jilid Satu, Edisi ke 9. Jakarta: PT. Indeks Kelompok Gramedia.

Scoot, J.V., and D.L Davis. (1990). The Relationship Between Etics and job Satification : An Empirical Investigation, Journal of bisnees Ethic, 9: 489-494.

Siagian, S.P. (2002). Manajemen Sumber Daya Manusia, Jakarta: Bumi Aksara.

Simamora, H. (2001). Manajemen Sumberdaya Manusia, edisikedua. Yogyakarta: YKPN.

Santoso, S. (2001). Analisis Multivariate Analysis. Jakarta: Gramedia Pustaka.

Tsui, A.S., Peace, J.L., dan Poter, L.W. 1997. Dalam Mas,sud, Fuad. (2004). Survei Diagnosis Organisasional Konsep dan Aplikasi. Semarang: Badan Penerbit Universitas Dipenegoro.

Undang - undang No.13 tahun 2003. Pasal 50-59

Undang - undang No.13 tahun 2003. Pasal 64, 65, 66

Venkatesan, R. (1992). Strategic Sourcing: to Make or Not to Make, Harvard Business Review, 70 (6): 98-107.

Widiastra, I.K., and Darma, G.S. (2015). Komitmen, Kepuasan Kerja, Organizational Citizenship Behavior dan Kinerja Pegawai Kontrak, Jurnal Manajemen \& Bisnis, 12 (2): 214-241.

Widiari, I.A.R., and Darma, G.S. (2017). Evaluasi Kinerja Pegawai Kontrak Melalui Tujuh Kompetensi Spencer Pada Pelayanan Denpasar Sewerage Development Project (DSDP), Jurnal Ilmiah Manajemen \& Bisnis, 2 (2): 360-367. 